\title{
Elevation of specific immunoglobulin A antibodies to both allergen and bacterial antigen in induced sputum from asthmatics
}

\author{
D-H. Nahm, H-Y. Kim, H-S. Park
}

Elevation of specific immunoglobulin A antibodies to both allergen and bacterial antigen in induced sputum from asthmatics. D-H. Nahm, H-Y. Kim, H-S. Park. OERS Journals Ltd 1998. ABSTRACT: The antigenic specificity and pathogenetic significance of immunoglobulins in airway secretion from asthmatic patients have not been established. Elevated levels of B-cells and immunoglobulin (Ig)A antibodies have been reported in sputum of asthmatics and these levels correlated with the eosinophil counts and levels of degranulated cytotoxic proteins from eosinophils. This study aimed to investigate the antigen specificity and possible pathogenetic significance of antibodies in airway secretion from asthmatic patients.

Specific IgA and IgG antibodies to both allergen (Dermatophagoides farinae) and bacterial antigen (capsular polysaccharide antigen from Streptococcus pneumoniae) were measured in sputum from 16 atopic asthmatic patients sensitized to $D$. farinae and 12 nonatopic, nonasthmatic controls by enzyme-linked immunosorbent assay. Sputum was induced by inhalation of hypertonic saline. Eosinophil cationic protein (ECP) levels in sputum from asthmatic patients were measured by the Pharmacia CAP system.

Levels of IgA to both $D$. farinae and $S$. pneumoniae and IgG to D. farinae in the sputum from asthmatic patients were significantly higher than those from controls $(\mathbf{p}<\mathbf{0 . 0 0 5})$. No significant difference was found in the levels of IgG to $S$. pneumoniae between the two groups. In asthmatic patients, there were significant correlations between IgA to $D$. farinae and $S$. pneumoniae $(\mathrm{r}=0.76, \mathrm{p}=0.003)$. Sputum ECP levels correlated significantly with $\operatorname{IgA}$ to $D$. farinae $(\mathrm{r}=0.55, \mathrm{p}=0.03)$ and $S$. pneumoniae $(\mathrm{r}=0.56, \mathrm{p}=0.03)$ and IgG to $D$. farinae $(\mathrm{r}=0.52, \mathrm{p}=0.04)$, but not with IgG to $S$. pneumoniae in asthmatic patients.

In conclusion, specific immunoglobulin $A$ antibodies to both allergen and bacterial antigen were elevated in induced sputum from atopic asthmatics and their possible involvement in eosinophil degranulation was suggested. Eur Respir J 1998; 12: 540-545.

Dept of Allergy and Clinical Immunology, Ajou University School of Medicine, Suwon, Kyung-Ki-Do, Korea.

Correspondence: H-S. Park

Dept of Allergy and Clinical Immunology Ajou University School of Medicine Suwon

Kyung-Ki-Do

Korea, 442-749

Fax: 823312195109

Keywords: Antibody asthma

eosinophil cationic protein

house dust mite

induced sputum

Streptococcus pneumoniae

Received: October 301997

Accepted after revision April 171998

Supported by KOSEF Grant 981-0701003-2 to D.H. Nahm.
Airway secretion on the respiratory mucosa is an important part of mucosal immunity [1] and the presence of immunoglobulin (Ig)A, IgG, IgM and IgE antibodies in airway secretion has been shown [2]. In airway secretion, IgA (60-70\%) and IgG (30-40\%) antibodies account for $99 \%$ of total immunoglobulins [3, 4] and the majority $(70-90 \%)$ of total $\operatorname{IgA}$ is secretory $\operatorname{IgA}$ which is locally produced in the respiratory mucosa $[3,4]$. It has been suggested that a majority of IgG antibodies in airway secretion are passively leaked through the surface epithelium from the systemic circulation $[1,5]$. A protective role of mucosal IgA antibodies in various bacterial and viral infections has been suggested $[1,2]$. However, the significance of mucosal immunoglobulins in the pathogenesis of chronic airway disease has not been fully determined.

Eosinophils play a major role in the airway inflammation of bronchial asthma [6]. Cytotoxic proteins released by eosinophil degranulation are believed to play a central role in the pathogenesis of bronchial asthma by inducing damage to the airway epithelium [7]. However, the mechanism of eosinophil degranulation in asthmatic airway is

For editorial comments see page 517. poorly understood [8]. Various chemoattractants and cytokines such as platelet-activating factor (PAF), interleukin (IL)-3, IL-5, and granulocyte-macrophage colony-stimulating factor (GM-CSF) are known to affect eosinophil migration, proliferation and survival, but they act as a weak degranulation inducers for eosinophils and act mainly as priming agents [8]. In vitro studies have suggested that immobilized $\operatorname{IgG}$ and $\operatorname{IgA}$, and secretory $\operatorname{IgA}$ can stimulate eosinophil degranulation; of these immunoglobulins, secretory $\operatorname{Ig} \mathrm{A}$ is the best for inducing eosinophil degranulation without stimulating neutrophil degranulation [8]. In parasitic disease, it has been suggested that $\operatorname{IgA}$ antibody participates in antibody-dependent eosinophil-mediated cytotoxicity by inducing eosinophil degranulation and thereby protects against parasitic infections [9]. Recent studies on IgA antibody in induced sputum by the present authors [10] and others [11] showed that total IgA antibody levels correlate significantly with eosinophil cationic protein (ECP) levels and eosinophil counts in induced sputum from asthmatic patients and suggested that $\operatorname{IgA}$ antibodies in tracheobronchial secretion may be involved in eosinophil degranulation in the bronchial mucosa of asthmatic patients. 
The respiratory mucosa responds to various bacterial organisms and inhaled airborne allergens. Patients with chronic airway disease showed elevated levels of IgA antibody against bacterial antigen in their sputum [12], whereas, patients with bronchial asthma showed elevated levels of $\operatorname{IgA}$ antibody to inhalant allergen in sputum [13]. However, antigenic specificity of $\operatorname{IgA}$ antibodies in airway secretion from asthmatic patients has not been fully determined.

To investigate the antigen specificity and possible pathogenetic significance of $\operatorname{IgA}$ and IgG antibodies in the airway secretion from patients with asthma, IgA and IgG antibodies to allergen and bacterial antigen were measured in induced sputum from patients with atopic asthma.

\section{Methods}

\section{Subjects}

Induced sputum samples were collected from 16 atopic asthmatic patients who showed a positive response to house dust mite (Dermatophagoides farinae; Bencard Co., Brentford, UK) on a skin-prick test (table 1). All patients had a typical clinical history of asthma and documented reversibility of forced expiratory volume in one second (FEV1) $>15 \%$ of predicted value. All patients were nonsmokers and had a mild degree of asthma. None had received inhaled or oral corticosteroids for at least 3 months before the study. Subjects who had suffered a recent respiratory tract infection or exacerbation of asthma were excluded. Twelve healthy, nonatopic, nonsmoking and nonasthmatic controls were recruited from the medical students and staff of Ajou University Hospital. Some of the asthmatic subjects and all of the controls were participants in the previous study [10]. All subjects underwent a skinprick test with common aeroallergens (house dust mite, grass pollens, tree pollens, weed pollens, cat, dog and moulds; Bencard Co.). A positive skin test was defined when the mean wheal diameter of the allergen was $3 \mathrm{~mm}$ greater than that of the negative control (normal saline). This study was approved by the Ethics Committee of Ajou University Hospital and all subjects gave their written informed consent. The study was conducted from July to August 1995, during the season when the environmental house dust mite allergen reaches peak levels in Korea [14].

\section{Sputum and saliva sampling}

Sputum was induced according to the method previously described [15]. Immediately before sputum induction,

Table 1. - Characteristics of the study subjects

\begin{tabular}{lcc}
\hline & $\begin{array}{c}\text { Healthy } \\
\text { controls } \\
(\mathrm{n}=12)\end{array}$ & $\begin{array}{c}\text { Asthmatic } \\
\text { subjects } \\
(\mathrm{n}=16)\end{array}$ \\
\hline Age yrs (mean $\pm \mathrm{sD})$ & $35 \pm 11$ & $36 \pm 14$ \\
Sex M/F & $5 / 7$ & $10 / 6$ \\
FEV1\% & $101.4 \pm 1.7$ & $87.3 \pm 4.5^{*}$ \\
Sputum eosinophil count & $0.5 \pm 0.4$ & $14.4 \pm 4.6^{*}$ \\
Sputum ECP ng.mL-1 & - & $231.6 \pm 44.3$ \\
Sputum total IgA $\mu g \cdot \mathrm{mL}^{-1}$ & $196 \pm 32$ & $328 \pm 57$ \\
Sputum total IgG $\mu \mathrm{g} \cdot \mathrm{mL}^{-1}$ & $60.8 \pm 12.2$ & $226.2 \pm 80.9$ \\
\hline
\end{tabular}

Values are presented as mean \pm SEM except where indicated. M: male; F: female; FEV1: forced expiratory volume in one second; ECP: eosinophil cationic protein; Ig: immunoglobulin. *: $\mathrm{p}<0.05$, significant difference between groups. -: not measured. each subject was pretreated with $200 \mu \mathrm{g}$ salbutamol, administered by means of a metered-dose inhaler. The subjects then inhaled nebulized sterile $3 \%$ saline solution for 20 min through an ultrasonic nebulizer (Omron Co., Tokyo, Japan). Subjects were encouraged to cough throughout the procedure and they regularly stopped to expectorate sputum. Before sputum expectoration, each subject was instructed to rinse their mouth with water and blow their nose, then to cough and expectorate sputum into a clean plastic container. Saliva samples were taken before induction of sputum in 12 asthmatic patients.

\section{Processing of sputum and saliva}

Collected sputum and saliva were processed immediately as in the method previously described [10]. The volumes of saliva and induced sputum were determined and an equal volume of phosphate-buffered saline (PBS) was added. The samples were then mixed using a vortex mixer and centrifuged for $20 \mathrm{~min}$ at $1,500 \times \mathrm{g}$. The supernatants were aspirated and frozen at $-20^{\circ} \mathrm{C}$. The pellets were further treated with dithiothrietol (Sputolysin; Calbiochem Biochemicals, San Diego, CA, USA) as described previously [15], resuspended in saline, cytocentrifuged (Model 7 cytospin; Shadon Scientific Products, Miami, FL, USA) and stained by the Wright-Giemsa method. Eosinophils were counted from at least 200 nonsquamous cells on each slide.

\section{Measurement of total immunoglobulin levels}

Total IgA concentrations in induced sputum were measured by nephelometry with a Beckman Array System (Beckman Instruments, Brea, CA, USA). Total IgG concentrations in induced sputum were measured by a sandwich enzyme-linked immunosorbent assay (ELISA) method using affinity-purified polyclonal goat antibodies to human IgG (Sigma Chemical Co., St Louis, MO, USA) as described previously [4].

\section{ECP measurement}

The ECP level in induced sputum was measured using the Pharmacia CAP system (Pharmacia Diagnostics, Uppsala, Sweden) in 16 asthmatic patients. The lowest detection limit for ECP measurement was $2 \mathrm{ng} \cdot \mathrm{mL}^{-1}$. When ECP levels were below the lowest detection limit, they were treated as zero for statistical analysis.

Measurement of specific antibodies to house dust mite (Dermatophagoides farinae) and Streptococcus pneumoniae antigens

Specific antibodies to D. farinae and Streptococcus pneumoniae antigens were measured by ELISA according to the method reported previously $[12,13,16]$. Microtitre plates (Immulon 2; Dynatech Laboratories, Chantilly, VA, USA) were coated with either D. farinae antigen (kindly provided by J. Weiss at Diagnostic Products Corporation, Los Angeles, CA, USA) at a concentration of $2 \mu \mathrm{g} \cdot \mathrm{well}-1$ in $0.1 \mathrm{M}$ carbonate buffer ( $\mathrm{pH} 9.6$ ) and pneumococc- al polysaccharide antigens (mixed antigens from 23 serotypes, Pasteur Méieux Sérums et Vaccins, Lyon, France) at a concentration of $0.1 \mu \mathrm{g} \cdot \mathrm{well}^{-1}$ in PBS, overnight at 
$4^{\circ} \mathrm{C}$. Plates were washed and blocked with $3 \%$ bovine serum albumin in PBS with $0.05 \%$ Tween-20 and then incubated with duplicated samples $(50 \mu \mathrm{L})$ of induced sputum and saliva at 1:50 dilutions overnight at $4^{\circ} \mathrm{C}$. After washing, plates were incubated with peroxidase-conjugated affinity-purified goat anti-IgA or anti-IgG antibodies (Sigma) at 1:2,500 dilution for $3 \mathrm{~h}$ at room temperature. After washing, the substrate solution consisting of $0.04 \%$ $(\mathrm{w} / \mathrm{v})$ orthophenylenediamine (OPD) dissolved in $24.3 \mathrm{mM}$ citric acid, $51.4 \mathrm{mM} \mathrm{NaH} \mathrm{PO}_{4}\left(\mathrm{pH} \mathrm{5.0)}\right.$ and $0.03 \% \mathrm{H}_{2} \mathrm{O}_{2}$ was added. After $15 \mathrm{~min}$, the reaction was stopped by adding $2.5 \mathrm{~N} \mathrm{H}_{2} \mathrm{SO}_{4}$. Colour development was measured with an ELISA reader (Molecular Devices, Menlo Park, CA, USA) at $490 \mathrm{~nm}$. Amounts of specific antibodies in the samples were calculated from control curves made by optical densities from serial dilutions of positive control samples which showed high titre antibodies using a spline fit program (SoftMax, Molecular Devices). The specific antibody contents in the reference samples were designed as 100 arbitrary units (AU) $\cdot \mathrm{mL}^{-1}$. In each assay system intra-assay and interassay variations were below $15 \%$. To assess the parallelism between standard and samples, interdilutional variations of each assay were calculated and the values were below $15 \%$.

\section{ELISA inhibition}

ELISA inhibition was performed using sputum samples with high titre specific antibodies. Serially 10 -fold diluted $D$. farinae and $S$. pneumoniae polysaccharide antigens starting from $1 \mathrm{mg} \cdot \mathrm{mL}^{-1}$ were added to diluted positive sputum samples for $16 \mathrm{~h}$ at $4^{\circ} \mathrm{C}$ and the specific antibodies were measured by ELISA as described above. The results of ELISA inhibition were calculated as the per cent inhibition according to the following formula: Inhibition $(\%)=$ ((Absorbance by addition of buffer only - Absorbance by addition of antigen)/Absorbance by addition of buffer only) $\times 100$.

\section{Statistics}

Data were expressed as the mean and standard error of the mean (SEM). The Mann-Whitney U-test was used to assess differences between groups. A Spearman's rank correlation was calculated to assess correlations between the data. The differences between induced sputum and saliva samples from the same subjects were compared by a Wilcoxon signed-rank test. A p-value $<0.05$ was regarded as statistically significant.

\section{Results}

Levels of specific antibodies to Dermatophagoides farinae and Streptococcus pneumoniae in induced sputum

Levels of IgA to both D. farinae and S. pneumoniae and IgG to $D$. farinae in sputum from asthmatic patients were significantly higher than those from controls $(p<0.005)$ (fig. 1). No significant difference was found in the levels of IgG to $S$. pneumoniae between the two groups ( $\mathrm{p}>0.05$ ).
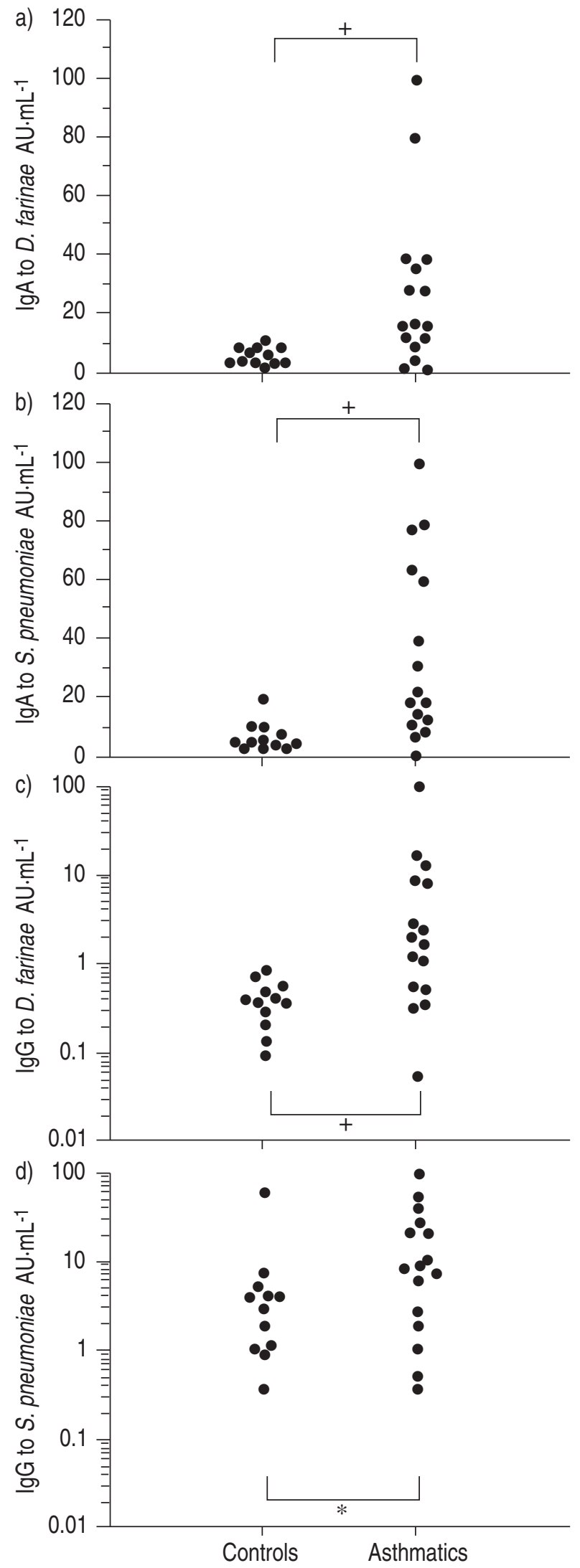

Fig. 1. - Levels of specific immunoglobulin (Ig)A (a, b) and specific IgG antibodies (c, d) to Dermatophagoides farinae and Streptococcus pneumoniae in induced sputum from controls and asthmatics. *: p> $0.05 ;+: \mathrm{p}<0.005$, significant difference between groups. 

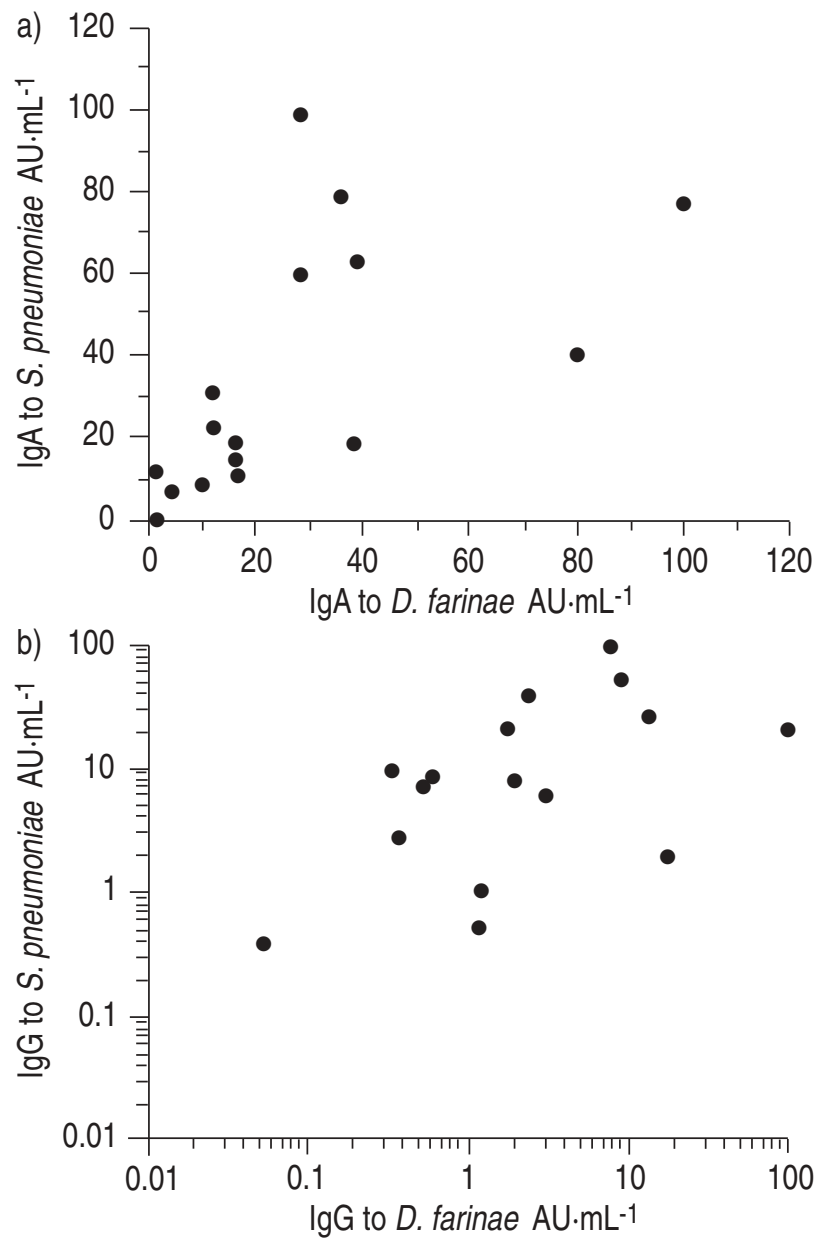

Fig. 2. - Correlations between a) specific immunoglobulin (Ig)A antibodies to Dermatophagoides farinae and b) Streptococcus pneumoniae and between specific IgG antibodies to $D$. farinae and $S$. pneumoniae in induced sputum from mite-sensitive asthmatic patients. a) $\mathrm{r}=0.76, \mathrm{p}=$ $0.003, \mathrm{n}=16$; b) $\mathrm{r}=0.49, \mathrm{p}=0.06, \mathrm{n}=16$.

\section{ELISA inhibition}

Dermatophagoides farinae and S. pneumoniae antigen inhibited specific antibody bindings over $80 \%$ in each specific IgG and IgA assay in a dose-dependent manner and there was no evidence of cross-antigenicity between the two antigens (data not shown).

Table 2. - Correlations between immunoglobulin levels and eosinophil counts (\%) or eosinophil cationic protein (ECP) levels in induced sputum from asthmatic patients $(n=16)$

\begin{tabular}{|c|c|c|c|c|}
\hline & \multicolumn{2}{|c|}{$\begin{array}{c}\text { Sputum } \\
\text { eosinophil count }\end{array}$} & \multicolumn{2}{|c|}{ ECP } \\
\hline & $\mathrm{r}$ & p-value & $\mathrm{r}$ & $\mathrm{p}$-value \\
\hline Total IgA & 0.50 & 0.053 & 0.82 & 0.002 \\
\hline Total IgG & 0.45 & 0.21 & 0.42 & 0.10 \\
\hline Specific IgA to D. farinae & 0.31 & 0.26 & 0.55 & 0.03 \\
\hline Specific IgG to D. farinae & 0.33 & 0.20 & 0.52 & 0.04 \\
\hline Specific IgA to $S$. pneumoniae & 0.32 & 0.21 & 0.56 & 0.03 \\
\hline Specific IgG to $S$. pneumoniae & 0.33 & 0.20 & 0.30 & 0.25 \\
\hline
\end{tabular}

Ig: immunoglobulin; $D$. farinae: Dermatophagoides farinae; $S$. pneumoniae: Streptococcus pneumoniae.
Table 3. - Fluid phase measurements in induced sputum and saliva from 12 asthmatic patients

\begin{tabular}{lcc}
\hline & $\begin{array}{c}\text { Induced } \\
\text { sputum }\end{array}$ & Saliva \\
\hline Total IgA $\mu \mathrm{g} \cdot \mathrm{mL}^{-1}$ & $337 \pm 74$ & $120 \pm 23^{*}$ \\
Total IgG $\mu \mathrm{g} \cdot \mathrm{mL}^{-1}$ & $240.7 \pm 105.9$ & $14.3 \pm 3.2^{* * *}$ \\
Specific IgA to $D$. farinae & $29.4 \pm 8.7$ & $4.8 \pm 1.2^{* * *}$ \\
AU.mL-1 & & \\
Specific IgG to $D$. farinae & $12.7 \pm 8.1$ & $0.28 \pm 0.13^{* * *}$ \\
AU.mL-1 & & \\
Specific IgA to $S$. pneumoniae & $38.4 \pm 9.5$ & $4.6 \pm 1.6^{* * *}$ \\
AU.mL-1 & & \\
Specific IgG to $S$. pneumoniae & $20.4 \pm 8.5$ & $0.38 \pm 0.10^{* * *}$ \\
AU.mL-1 & & \\
\hline
\end{tabular}

Values are presented as mean \pm SEM. Ig: immunoglobulin; $D$. farinae: Dermatophagoides farinae; S. pneumoniae: Streptococcus pneumoniae. $*: \mathrm{p}<0.05$; $* * *: \mathrm{p}<0.001$, significant difference between groups.

Correlations between fluid-phase measurements of immunoglobulins in induced sputum from asthmatic patients

There were significant correlations between $\operatorname{IgA}$ to $D$. farinae and $\operatorname{IgA}$ to $S$. pneumoniae ( $\mathrm{r}=0.76, \mathrm{p}=0.003)$. However, there was a weaker borderline significant correlation between $\mathrm{IgG}$ to $D$. farinae and $\mathrm{IgG}$ to $S$. pneumoniae ( $\mathrm{r}=0.49, \mathrm{p}=0.06)$ (fig. 2$)$.

Correlations between immunoglobulin levels and eosinophil counts or ECP levels in induced sputum from asthmatic patients

There was no significant correlation between eosinophil counts $(\%)$ and immunoglobulin levels in induced sputum from asthmatic patients ( $>>0.05)$ (table 2). In asthmatic patients, levels of sputum ECP correlated significantly with those of total $\operatorname{IgA}(\mathrm{r}=0.82, \mathrm{p}=0.002), \operatorname{IgA}$ to $D$. farinae $(\mathrm{r}=0.55, \mathrm{p}=0.03)$, IgA to $S$. pneumoniae $(\mathrm{r}=0.56, \mathrm{p}=$ 0.03 ) and $\mathrm{IgG}$ to $D$. farinae ( $\mathrm{r}=0.52, \mathrm{p}=0.04)$, but not with total $\mathrm{IgG}(\mathrm{r}=0.42, \mathrm{p}=0.1)$ or $\mathrm{IgG}$ to $S$. pneumoniae $(\mathrm{r}=$ $0.30, \mathrm{p}=0.25)$ (table 2).

Levels of specific antibodies to S. pneumoniae in induced sputum and saliva from 12 asthmatic patients

All fluid-phase measurements including total IgA, total $\mathrm{IgG}$, specific $\operatorname{IgA}$ and $\mathrm{IgG}$ antibodies to both $S$. pneumoniae and $D$. farinae were significantly higher in induced sputum than in saliva from 12 asthmatic patients (total $\operatorname{IgA}$, $\mathrm{p}<0.05$; others, $\mathrm{p}<0.001$ ) (table 3 ).

\section{Discussion}

This study demonstrated that IgA antibodies to both allergen and bacterial antigen are elevated in induced sputum samples from atopic asthmatic patients. Elevations of B-cells [17] and IgA antibodies [11] in induced sputum of asthmatics have been reported. Although increased levels of allergen-specific IgE, IgG and IgA antibodies in nasal 
secretions from patients with allergic rhinitis [18] and house dust mite-specific IgA antibodies in sputum from mite-sensitive asthmatic patients have been reported [13], information on the antigen specificity of these antibodies in airway secretion from asthmatic patients has been limited. In this study, it was demonstrated that $\operatorname{IgA}$ antibodies to both house dust mite antigen and pneumococcal polysaccharide antigen are increased in induced sputum from mite-sensitive asthmatic patients.

In a previous study, we demonstrated that the majority of $\operatorname{IgA}$ antibodies in induced sputum from atopic asthmatics was not diffused out passively from the systemic circulation but produced locally [10]. There are several possible explanations for the elevation of $\operatorname{IgA}$ antibodies to pneumococcal polysaccharide antigen in induced sputum from mite-sensitive asthmatic patients.

The first explanation is infection or colonization of $S$. pneumoniae in the airway mucosa and stimulation of IgA antibody response in asthmatic patients. It is known that $S$. pneumoniae inhabit the upper respiratory tract of healthy adults and patients with chronic obstructive pulmonary disease (COPD) [19]. Only a small proportion of patients with COPD $(\sim 7 \%)$ was found to have colonization of the lower respiratory tract by $S$. pneumoniae [20, 21]. As the patients included in this study did not have any clinical symptoms or signs suggesting respiratory infection, the possibility of pneumococcal infection in the majority of these patients seems to be very low.

Another possibility is nonspecific expansion of pre-existing IgA-producing B cells in the airway mucosa due to increased levels of IL-5 in the airway secretion of asthmatic patients [22]. In in vitro conditions, IL-5 acts on B cells to enhance the production of IgA antibodies [23] and the application of recombinant IL-5 on to human nasal mucosa increases the production of $\operatorname{IgA}$ antibodies in nasal secretion [24]. Inhalation of allergen could increase the concentration of IL-5 in airway secretions from atopic asthmatics [25]. Capsular polysaccharide antigen of $S$. pneumoniae is one of the thymus-independent antigens and a humoral immune response against this antigen does not depend on the presence of antigen-specific $\mathrm{T}$ cells, although T-cell factors are required [26]. It may be speculated that activation of house dust mite-specific T-lymphocytes with natural allergen exposure results in overproduction of IL-5, stimulating both house dust mite-specific B-cells and $S$. pneumoniae-specific B-cells in the bronchial mucosa to produce specific IgA antibodies. The significant close quan-titative correlations between specific IgA antibodies to house dust mite antigen and pneumococcal polysaccharide antigen in this study also support this hypothesis.

A significant correlation between sputum eosinophilia and B-cell counts in asthmatic patients has been reported [17] and the levels of soluble marker for eosinophil activation (ECP) correlated significantly with total IgA levels in induced sputum of asthmatic patients $[10,11]$. These results suggest a possible contribution of B-cell and IgA antibodies to the pathogenesis of eosinophilic inflammation of the asthmatic airway; however, their exact role in the pathogenesis of asthma is still undefined. Several in vitro data have suggested that immunoglobulins in respiratory secretions may participate in eosinophil degranulation in respiratory allergic diseases [8], although only a few in vivo data have supported this hypothesis $[10,11]$. In in vitro conditions, immobilization of immunoglobulins on a solid phase is essential in immunoglobulin-induced eosinophil degranulation and plastic beads have been used for this purpose [8]. However, solid-phase matrices to immobilize immunoglobulins for eosinophil degranulation were not defined in the asthmatic airway.

Allergen present in the airway mucosa could be a potential candidate. The allergen coated on a microtitre plate can degranulate eosinophils in the presence of sera from patients sensitized to the same allergen [27]. Moreover, the amounts of eosinophil degranulation correlated with the level of allergen-specific antibodies in the serum and depletion of allergen-specific antibodies abolished the eosinophil degranulation [27]. Recently, the same group reported that bronchoalveolar lavage (BAL) fluid obtained from ragweed-sensitive asthma after segmental allergen challenge could induce eosinophil degranulation on allergencoated plastic surfaces and they also revealed significant correlations between amounts of eosinophil degranulation and specific $\operatorname{IgG}$ and $\operatorname{IgA}$ antibodies to ragweed in BAL fluid [28]. In this study, significant correlations were found between the levels of ECP, and IgA and IgG antibodies to house dust mite in induced sputum from mite-sensitive asthmatic patients. The patients may have been in a state of continuous low-dose allergen challenge, because this study was undertaken during the period when environmental house dust mite allergen reaches peak levels in Korea [14]. These findings suggest that allergen-specific IgG and IgA antibodies in the airway secretion may contribute to allergic inflammation by stimulating eosinophil degranulation.

Sputum induction is a useful, reliable and noninvasive method for obtaining airway secretion from asthmatic patients [29-31]. Most previous studies on bronchial asthma using induced sputum have focused on inflammatory cells and mediators [15, 29-31] and only rarely have studies dealt with allergen-specific antibodies. One of the disadvantages of studying proteins from induced sputum is the contamination of oropharyngeal secretions including saliva. To overcome this problem, two sampling methods were tried. Firstly, mucus plugs were extracted from sputum samples to minimize salivary contamination [29]. Secondly, the entire induced sputum sample was analysed and compared with the results from the saliva [15]. In this study, the latter method was used because selection of a mucus plug provides more viscous samples as well as smaller amounts of specimen for fluid-phase analysis. The levels of total IgA, total IgG, antigen-specific IgA and IgG antibodies in induced sputum samples from asthmatic patients were significantly higher than those in salivary samples. These results suggest that the majority of $\operatorname{IgA}$ and $\mathrm{IgG}$ antibodies in induced sputum may originate from subglottic airways and sputum induction is a useful noninvasive tool for studying allergen-specific antibodies in airway secretions from asthmatic patients.

In conclusion, specific immunoglobulin $\mathrm{A}$ antibodies to both allergen and bacterial antigen were elevated in induced sputum from atopic asthmatics and their possible involvement in eosinophil degranulation was suggested. Further study may be essential to clarify the pathogenetic role of immunoglobulins in asthmatic airways.

Acknowledgements: The authors thank the subjects who volunteered in this study and $\mathrm{H}$. Yu for reviewing the manuscript. 


\section{References}

1. Brandtzaeg P. The role of humoral mucosal immunity in the induction and maintenance of chronic airway infections. Am J Respir Crit Care Med 1995; 151: 2081-2087.

2. Burnett D. Immunoglobulins in the lung. Thorax 1986; 41: 337-344.

3. Deuschl H, Johansson SGO. Immunoglobulins in tracheo-bronchial secretion with special reference to IgE. Clin Exp Immunol 1974; 16: 401-412.

4. Peebles RS, Liu MC, Lichtenstein LM, Hamilton RG. $\mathrm{IgA}, \mathrm{IgG}$ and IgM quantification in bronchoalveolar lavage fluids from allergic rhinitics, allergic asthmatics, and normal subjects by monoclonal antibody-based immunoenzymetric assays. J Immunol Meth 1995; 179: 77-86.

5. Out TA, Van De Graaf EA, Jansen HM. Permeability or local production of immunoglobulins and other inflammatory proteins in asthma. Eur Respir J 1991; Suppl. 13, 148s-155s.

6. Gleich GJ. The eosinophil and bronchial asthma: current understanding. J Allergy Clin Immunol 1990; 85: 422436.

7. Filley WV, Holley KE, Kephart GM, Gleich GJ. Identification by immunofluorescence of eosinophil granule major basic protein in lung tissues of patients with bronchial asthma. Lancet 1982; ii: 11-16.

8. Martin LB, Kita H, Leiferman KM, Gleich GJ. Eosinophils in allergy: role in disease, degranulation, and cytokines. Int Arch Allergy Immunol 1996; 109: 207-215.

9. Dunne DW, Richardson BA, Jones FM, Clark M, Thorne KJ, Butterworth AE. The use of mouse/human chimaeric antibodies to investigate the roles of different antibody isotypes, including $\operatorname{Ig} \mathrm{A}_{2}$, in the killing of Schistosoma mansoni schistosomula by eosinophils. Parasite Immunol 1993; 15: 181-185.

10. Nahm DH, Park HS. Correlation between IgA antibody and eosinophil cationic protein levels in induced sputum from asthmatic patients. Clin Exp Allergy 1997; 27: 676681.

11. Louis R, Shute J, Biagi S, et al. Cell infiltration, ICAM-1 expression, and eosinophil chemotactic activity in asthmatic sputum. Am J Respir Crit Care Med 1997; 155: 466-472.

12. Groeneveld K, Eijk PP, Van Alphen L, Jansen HM, Zanen HC. Haemophilus influenzae infections in patients with chronic obstructive pulmonary disease despite specific antibodies in serum and sputum. Am Rev Respir Dis 1990; 141: 1316-1321.

13. Kitani S, Ito K, Miyamoto T. IgG, IgA, and IgM antibodies to mite in sera and sputa from asthmatic patients. Ann Allergy 1985; 55: 612-620.

14. Nahm DH, Park HS, Kang SS, Hong CS. Seasonal variation of skin reactivity and specific $\operatorname{IgE}$ antibody to house dust mite. Ann Allergy Asthma Immunol 1997; 78: 589-593.

15. Fahy JV, Liu J, Wong H, Boushey HA. Cellular and biochemical analysis of induced sputum from asthmatic and from healthy subjects. Am Rev Respir Dis 1993; 147: 1126-1131.

16. Bruyn GAW, Hiemstra PS, Van Der Lans AM, Van Furth R. Pneumococcal anticapsular antibodies in patients with chronic cardiovascular and obstructive lung disease in the Netherlands. J Infect Dis 1990; 162: 1192-1194.
17. Kidney JC, Wong AG, Efthimiadis A, et al. Elevated B cells in sputum of asthmatics: close correlation with eosinophils. Am J Respir Crit Care Med 1996; 153: 540544.

18. Platts-Mills TAE. Local production of $\operatorname{IgG}, \operatorname{IgA}$, and $\operatorname{IgE}$ antibodies in grass pollen hay fever. J Immunol 1979; 22: 2218-2225.

19. Murphy TF, Sethi S. Bacterial infection in chronic obstructive pulmonary disease. Am Rev Respir Dis 1992; 146: $1067-1083$.

20. Cabello H, Torres A, Celis R, et al. Bacterial colonization of distal airways in healthy subjects and chronic lung disease: a bronchoscopic study. Eur Respir J 1997; 10: 11371144.

21. Riise GC, Ahlstedt S, Larsson S, et al. Bronchial inflammation in chronic bronchitis assessed by measurement of cell products in bronchial lavage fluid. Thorax 1995; 50: 360-365.

22. Walker C, Bode E, Boer L, Hansel TT, Blaser K, Virchow JC Jr. Allergic and nonallergic asthmatics have distinct patterns of T-cell activation and cytokine production in peripheral blood and bronchoalveolar lavage. Am Rev Respir Dis 1992; 146: 109-115.

23. Yokota T, Coffman RL, Hagiwara $\mathrm{H}$, et al. Isolation and characterization of lymphokine cDNA clones encoding mouse and human IgA-enhancing factor and eosinophil colony-stimulating factor activities: relationship to interleukin 5. Proc Natl Acad Sci USA 1987; 84: 7388-7392.

24. Terada N, Konno A, Tada H, Shirotori K, Ishikawa K, Togawa K. The effect of recombinant human interleukin-5 on eosinophil accumulation and degranulation in human nasal mucosa. J Allergy Clin Immunol 1992; 90: 160-168.

25. Jarjour NN, Calhoun WJ, Kelly EA, Gleich GJ, Schwartz LB, Busse WW. The immediate and late allergic response to segmental bronchopulmonary provocation in asthma. Am J Respir Crit Care Med 1997; 155: 1515-1521.

26. Peset Llopis MJ, Harms G, Hardonk MJ, Timens W. Human immune response to pneumococcal polysaccharides: complement-mediated localization preferentially on CD21-positive splenic marginal zone B cells and follicular dendritic cells. J Allergy Clin Immunol 1996; 97 : 1015-1024.

27. Kaneko M, Swanson M, Gleich GJ, Kita H. Allergen-specific $\mathrm{IgG}_{1}$ and $\mathrm{IgG}_{3}$ through $\mathrm{Fc} \gamma \mathrm{RII}$ induced eosinophil degranulation. J Clin Invest 1995; 95: 2813-2821.

28. Kaneko M, Jarjour N, Swanson M, Busse WW, Gleich GJ, Kita H. Allergen-specific IgG and IgA in bronchoalveolar lavage fluids from patients with allergy induce eosinophil degranulation. J Allergy Clin Immunol 1995; 95: 339 (Abstract).

29. Pin I, Gibson PG, Kolendowicz R, et al. Use of induced sputum cell counts to investigate airway inflammation in asthma. Thorax 1992; 47: 25-29.

30. Pizzichini E, Pizzichini MMM, Efthimiadis A, et al. Indices of airway inflammation in induced sputum: reproducibility and validity of cell and fluid-phase measurements. Am J Respir Crit Care Med 1996; 154: 308-317.

31. Fahy JV, Wong H, Liu J, Boushey HA. Comparison of samples collected by sputum induction and bronchoscopy from asthmatic and healthy subjects. Am J Respir Crit Care Med 1995; 152: 53-58. 